Asian Australas. J. Food Saf. Secur. 2019, 3 (2), 77-84

Asian-Australasian Journal of

Food Safety and Security

ISSN 2523-1073 (Print) 2523-2983 (Online)

www.ebupress.com/journal/aajfss

\title{
Article \\ Assessment of production vulnerability and food sufficiency in the southeastern parts of Bangladesh
}

\author{
Hafsa Jahan Hiya, Md. Suman Parvej and Murad Ahmed Farukh* \\ Department of Environmental Science, Bangladesh Agricultural University, Mymensingh-2202, Bangladesh
}

*Corresponding author: Professor Dr. Murad Ahmed Farukh, Department of Environmental Science, Bangladesh Agricultural University, Mymensingh-2202, Bangladesh. Phone: +8801712106603; E-mail: farukh_envsc@bau.edu.bd

Received: 30 October 2019/Accepted: 26 November 2019/ Published: 30 November 2019

\begin{abstract}
In a subsistence agrarian economy of Bangladesh, domestic food production has an important role to play in the quest for food security. The productivity in the agricultural sector is critically important if agricultural production is to increase at a sufficiently rapid rate to meet escalating demands for food. Bangladesh has pursued for decades a strategic goal of self-sufficiency in rice production. The country passed a major milestone in its efforts to achieve food security in the sense of rice grain availability at the national level at the end of the 1990s. Whatever progress been made would be difficult to sustain it due to high vulnerability of climatic shocks and the growing pressure of population on scarce natural resources thus, yet food security has not been achieved. The present study finds that, rice production is secure in Feni district from Chittagong division. Because rice production is greater than the consumption. On the other hand, Chandpur and Cox's Bazar district shows production insecurity in the very recent years. But Chittagong district has the production insufficiency from the past to present, because the production is insufficient to meet the demand of the vast population in this area. The study reveals that, the production of Aus rice will be increased in the next 5 years in Chittagong district. Aman rice production will be increased in the next 5 years in the districts namely Feni. Again, Boro rice production will be increased in the next 5 years in the districts namely Cox's bazar and Feni districts.
\end{abstract}

Keywords: food sufficiency; forecasting; rice production; vulnerability

\section{Introduction}

Rice is the most important extensively grown food crop and leading cereal in the world including Bangladesh. In Bangladesh, rice covers $75 \%$ of the total cropped area producing 29.75 million tons of rice grain having an average yield of $2.65 \mathrm{t} \mathrm{ha}^{-1}$ (Hossain et al., 2005). Bangladesh has a total area of 148.4 million hectares (Mha) and $67 \%$ of which is arable (BBS, 2008). About $1 \%$ of the total cultivable land is going out of agricultural use annually. The land-man ratio is decreasing at an alarming rate and the current estimated per capita arable land stands at 0.05 ha only. On the other hand, intensified agricultural land use accompanied with increased use of modern crop varieties has contributed to deterioration of soil health (Jahir et al., 2010). Bangladesh is a small country with a large population and each year, nearly 1.47 million people are added to its current population of about 164.2 million and at present population growth rate of $1.29 \%$ per year (BBS, 2011). It is an agrarian country and approximately $80 \%$ of its people depending on it for subsistence, where about one-fifth of GDP (20.01\%) comes from agriculture (BBS, 2012). So, Bangladesh's economy draws its main strength from agriculture sector.

In Bangladesh, the contributions of Boro, Aman and Aus rice production in 2010-11 were $55.50 \%, 38.81 \%$ and $5.69 \%$, respectively (BBS, 2011). During 1994-95 to 2008-09, rice yield has steadily increased from 16.83 to 34.22 million tons. It indicates an overall increase in production of cereal crops. The population of Bangladesh 
is still growing by two million every year and may increase by another 30 million over the next 20 years. Although food grain production has more than doubled since independence in 1971, food insecurity both in national and household level remains a matter of concern for the government. Food security encompasses three elements: availability, accessibility and utilization (Sattar and Moniruzzaman, 2008). Food availability refers as food sufficiency to the physical presence of food at various levels from household to national level, be that from own production or through markets (FANTA, 2006). Bangladesh has pursued for decades a strategic goal of self-sufficiency in cereal production. Whatever progress been made would be difficult to sustain it due to high vulnerability of climatic shocks and the growing pressure of population on scarce natural resources thus, yet food security has not been achieved. Availability of sufficient food at the country or local level does not mean that all people within that geographic unit are food secure. Food security implies that food intake must be adequate in both qualitative and quantitative terms. However, the issue of quality of diet has received little attention in the food-security debate at all levels. Bangladesh is at the cross-road in its efforts to achieve food security for its people. Over the past 30 years or so Bangladesh made significant achievement in food production and availability. But increases in cereal production have not been accompanied by significant rises in the availability of other foods (Gill et al., 2003).

The coastal region of Bangladesh covers $47,201 \mathrm{~km}^{2}$ land area which is $32 \%$ of the total geographical area of the country. According to population census of 2011, 38 million live in this region which is about $26.7 \%$ of the total population (BBS, 2011). The southeastern coastal and offshore area of Bangladesh includes tidal, estuaries and river floodplains in the south along the Bay of Bengal. Agricultural land use in these areas is very poor, which is roughly $50 \%$ of the country's average (Petersen and Shireen, 2001). Agriculture in Bangladesh is already under pressure both from huge and increasing demand for food and from problems of agricultural land and water resources depletion. The issue of global climate change makes it particularly difficult (Huq, 2003). It is a country that is highly susceptible to climate change, investigations of the influence of climate change on crop agriculture in this country have been limited. To reach the goal, it is necessary either to increase the crop area or yield per unit area. But due to high population pressure, horizontal expansion of land is not possible. Therefore, increasing yield per unit area is the only means, use of high yielding varieties and hybrid varieties in Bangladesh has been increased remarkably in recent years and the country has almost reached a level of selfsufficiency in rice production. There are several reports on this issue those are descriptive in nature. Ali (1999) discussed the influence of climate change by considering extreme climate events, such as cyclones, storm surges and coastal erosion and backwater effects. Rashid and Islam (2007) identified droughts, floods, soil salinity and cyclones as the major extreme climatic events that adversely affected agricultural production. In Bangladesh, such study has been done to analyze the rice grain production of different regions of Bangladesh but food sufficiency of different districts of Chittagong division of Bangladesh is relatively a new concept. Past records prevailed that very few study has been done to analyze the relationship between food consumption and food sufficiency. Under these circumstances a piece of research was conducted to assess food sufficiency and production vulnerability in the Chittagong division of Bangladesh, and for a probable forecasting of rice grain production for next few years.

\section{Materials and Methods}

\subsection{Selection of the study area}

To serve the purpose set for the study area is selected to collect information for analyzing production vulnerability and food sufficiency in Chittagong division, one of the southeastern coastal region of Bangladesh. The area were four districts of this division purposively selected - Chandpur, Chittagong, Cox's Bazar, Feni.

\subsection{Data collection and processing}

The required data were collected from different published and unpublished reports of Bangladesh Bureau of Statistics (BBS), Population Census 2011 and 2001, Directorate of Agricultural Extension (DAE), Household Income Expenditure Survey (HIES), Bangladesh Rice Research Institute (BRRI), Yearbook of Agricultural Statistics, and Statistical Yearbook of Bangladesh. All the collected data were analyzed using computer by prominent program (MS office). After data processing the data ware sorted for analyze.

\subsection{Data input and analysis}

Qualitative Data had been manually complied according to diverse issues considering the research sites. For data processing and analyzing, MS EXCEL has been used. 


\subsection{Assessment of food sufficiency}

\subsubsection{Assessment of rice grain production}

Three types of rice grain (Aus, Aman and Boro) production were estimated by metric ton unit.

Estimation of Total Aus production (Local + HYV), where HYV = High Yielding Variety.

Estimation of Total Aman production (Broadcast + L.T. + HYV), where L.T. = Local Transplant.

Estimation of Total Boro production (Local + HYV + Hybrid).

\subsubsection{Assessment of rice grain consumption}

\section{$\mathbf{C t}=\mathbf{P} * \mathbf{Y} * \mathbf{C}_{0} / \mathbf{1 0 0 0 0 0 0}(\mathbf{M T})$}

Where, $\mathrm{Ct}=$ Total consumption, $\mathrm{P}=$ Total people, $\mathrm{Y}=1$ year $/ 365$ days, $\mathrm{C}_{0}=$ Consumption person $^{-1}$ day $^{-1}=416$ $\mathrm{gm}$, Conversion of $1 \mathrm{MT}=1000000 \mathrm{gm}$.

Estimation of total people, $\mathbf{P}=\mathbf{P}_{\mathbf{0}}(\mathbf{1}+\mathbf{r} / \mathbf{1 0 0})^{\mathrm{n}}$

Where, $\mathrm{P}=$ No. of estimated people, $\mathrm{P}_{0}=$ No. of people of previous year, $\mathrm{r}=$ growth rate and $\mathrm{n}=$ year

\subsubsection{Assessment of rice grain sufficiency}

Food sufficiency was measured on the basis of the difference between total production of rice grain and total consumption.

\section{Sufficiency $=$ Total Production $($ MT) - Total Consumption $($ MT)}

\subsection{Forecasting of rice grain production}

Forecasting is the process of making predictions of the future based on past and present data and analysis of trends. A simple measurement technique is used here for forecasting of Chittagong division. Five years' forecasting from 2015-16 to 2019-20 of Aus, Aman, and Boro production are estimated using linear trend lines based on previous 7 years production data.

\section{Results and Discussion}

\subsection{Food sufficiency (FS)}

Food Sufficiency (FS) is usually defined as access to enough food by all people at all times to live active and healthy lives. In other words food security exists when all people, at all times, have physical and economic access to sufficient, safe and nutritious foods to meet their dietary needs and preferences for a healthy and active life (WFP, 2012). Major food items in Bangladesh are rice, wheat, pulses, potato, vegetables and fish. Rice alone contributes to $71 \%$ of the total per capita calorie and protein intake (BBS, 2008). From this discussion, it can be said that food sufficiency is strongly related to rice production. In this study, only rice grain (Aus, Aman and Boro) production and sufficiency were considered. From Chittagong division 4 districts such as Chandpur, Chittagong, Cox's Bazar and Feni were considered for assessing food sufficiency.

\subsubsection{Chandpur district}

Chandpur district is highly exposed to various climatic factors including variations in temperature, erratic behavior of rainfall, cyclonic events, droughts and salinity intrusion. These climatic factors are what make the lives of the people of this area vulnerable to climate change. Due to these causes, rice production is very much vulnerable in where the highest production was in 2009-10 because of the farmers are trying to cope with the consequences of the devastating cyclone "Sidr" which was struck in 2007. After that, the production gradually decreases from 2010-11 to 2013-14 (Figure 1). The population of Chandpur district is linearly increasing trend and as consumption is very much related to the total people so, the consumption is gradually increasing. Only in 2009-10 and 2010-11 consumption is lower than production that's why rice production is secure. But the remaining year's consumption is greater than production and there exists insecure rice production.

\subsubsection{Chittagong district}

Chittagong district has already been recognized as one of the most vulnerable district to landslide. The city dwellers of Chittagong experienced a terrible landslide. That's why the cultivable land is reducing day by day. There are many factors of low production of rice in Chittagong district. Such as, extended flooding of arable land narrowing scope for crop production, especially in the vast low land areas; increased inundation and salinity intrusion, limiting crop cultivation with the existing varieties, especially in the coastal regions; increased intensity of flush floods in Meghna basin and north eastern Haor region, damaging rice crop; increasing loss of land to river erosion, reducing land-based livelihood opportunities. There is also a vital cause of the reduction of 
rice production in Chittagong, which is land slide. Land slide is very devastating in Chittagong district. The people of Chittagong district is increasing linearly so the consumption of rice also increases. But the production in not increasing that's why here exists rice production insecure and the maximum insecure figure was in the year 2013-14 (Figure 2).

\subsubsection{Cox's Bazar district}

Rice production is increasing in 2008-09 to 2009-10, but from 2010-11 to 2014-15 it is gradually decreasing. The farmers convert their profession to others because they do not find extra benefit from rice farming otherwise the production cost is gradually increasing, so they are dishearten to rice cultivation. The area under rice production also decreasing gradually. Again, the population of Cox's Bazar district is increasing day by day, so the consumption also increases. There is a strong correlation between population growth and consumption rate. From the Figure 3, we can see the gap between production and consumption that was negative in the year 2013-14 and 2014-15. So rice production was insecure during that time.

\subsubsection{Feni district}

Feni district is vulnerable to various climatic events such as flood, heavy rainfall, droughts and salinity intrusions. Due to devastating cyclone "Sidr" (2007) and "Aila" (2009), rice production was lower in the year 2008-09 and 2009-10 (Figure 4). Again, the production increases in 2010-11 and 2011-12, because farmers think of getting relief from the hazardous events. But, the increasing production cost tends to change their motive. Again the introduction of high yielding variety gives more production from lower area. On the other hand, the production of rice is greater than the consumption in Feni district, so rice grain production is secure in this area.

\subsection{Forecasting of rice grain production}

\subsubsection{Chandpur district}

Figure 5 shows that the forecasting of Aus rice production in Chandpur district is increasing trend. From 200809 to 2014-15, Aus rice production has a gradual increasing trend. So, it can be anticipated that Chandpur district is favorable for Aus rice production.

\subsubsection{Chittagong district}

Five years' forecasting from 2015-16 to 2019-20 of Aus, Aman, and Boro production are estimated using linear trend line. Forecasting shows that, in Chittagong district Aus, Aman and Boro production will be increased in future (Figure 6), because previous production data shows increasing trend and $\mathrm{R}^{2}$ for Aus, Aman and Boro is $0.75,0.13$ and 0.12 , respectively.

\subsubsection{Cox's Bazar district}

Figure 7 shows that, in Cox's Bazar district Boro production forecasting has a linear increasing trend line. From the previous data, it is found that Cox's Bazar district is suitable for Boro rice production $\left(R^{2}=0.96\right)$.

\subsubsection{Feni district}

Linear trend line estimation shows that forecasting of the production of Aman and Boro rice will be increasing in the next 5 years. The entire phenomenon behind the production of Aman and Boro rice is favorable in Cox's Bazar district. Aman production shows higher increasing trend than Boro production and $\mathrm{R}^{2}$ for Aman and Boro is 0.62 and 0.28 , respectively (Figure 8). 


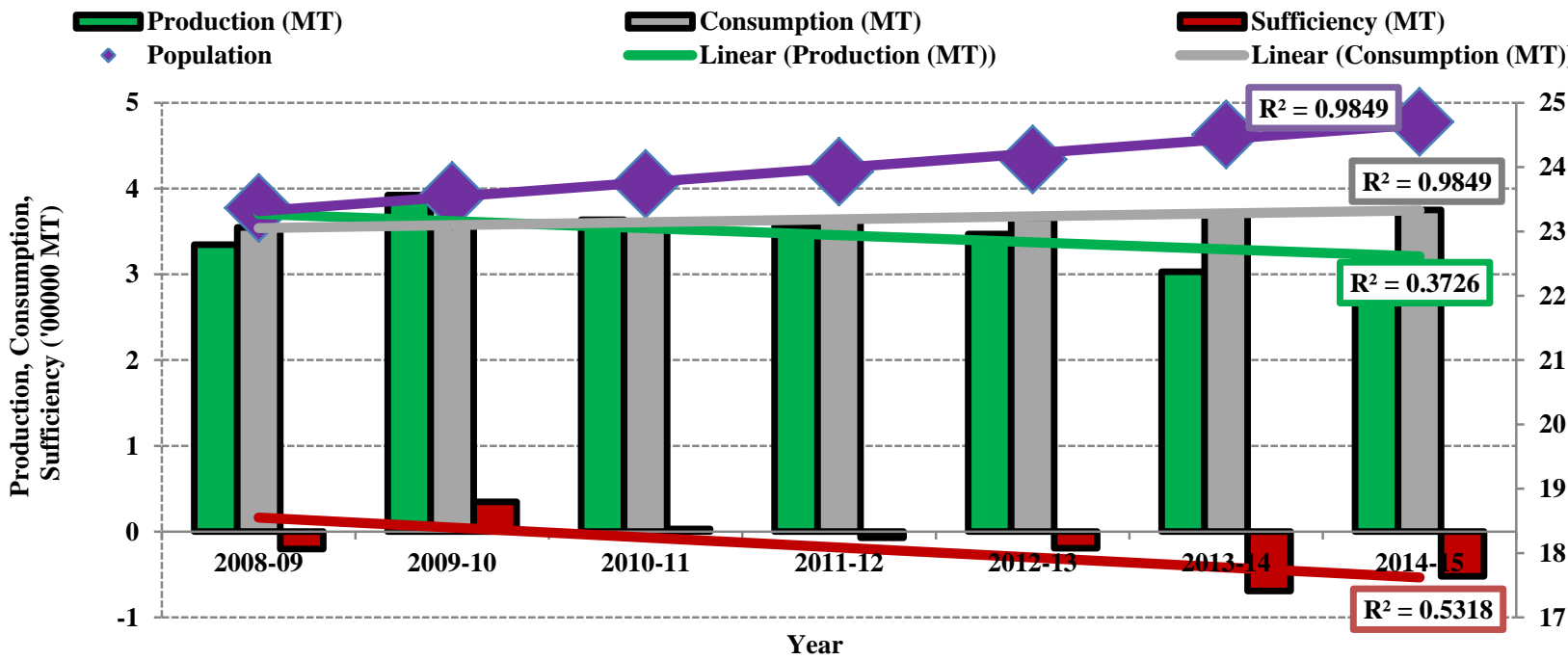

Figure 1. Food sufficiency in Chandpur district.

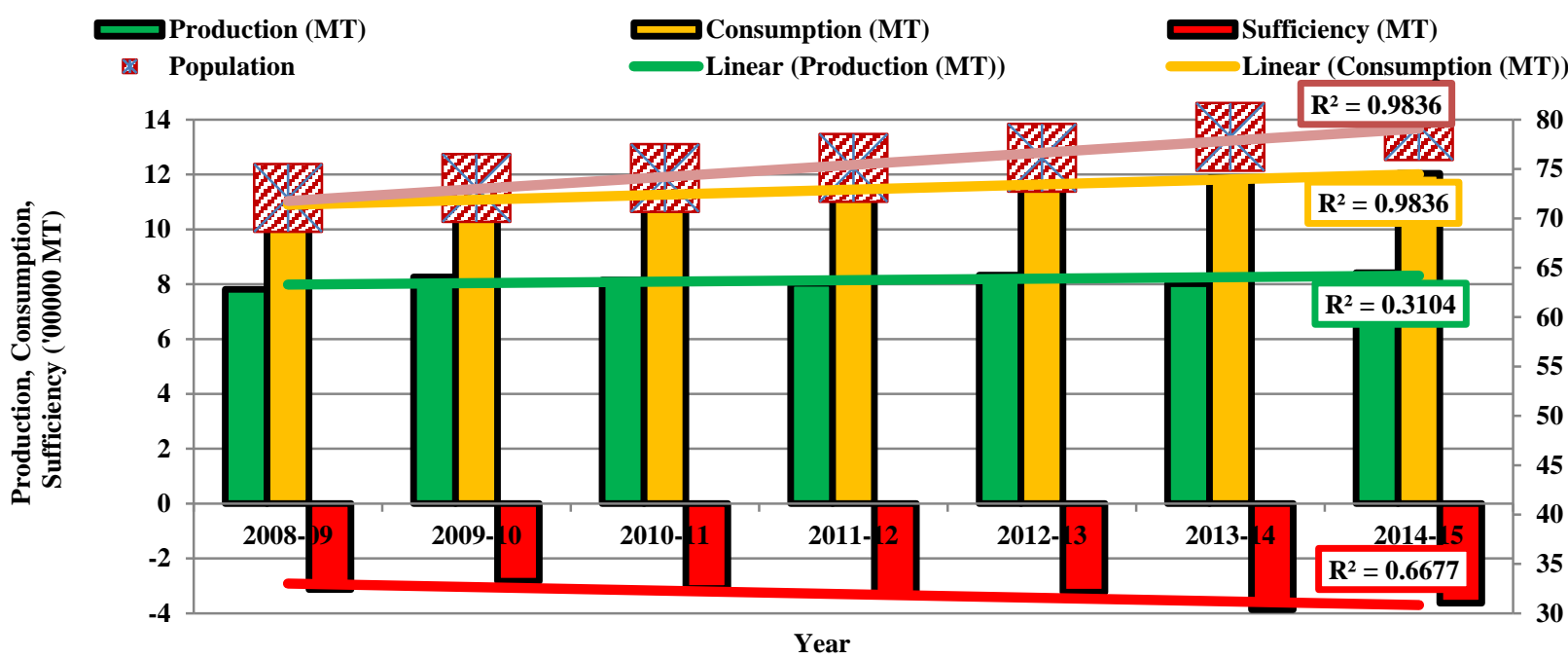

Figure 2. Food sufficiency in Chittagong district.

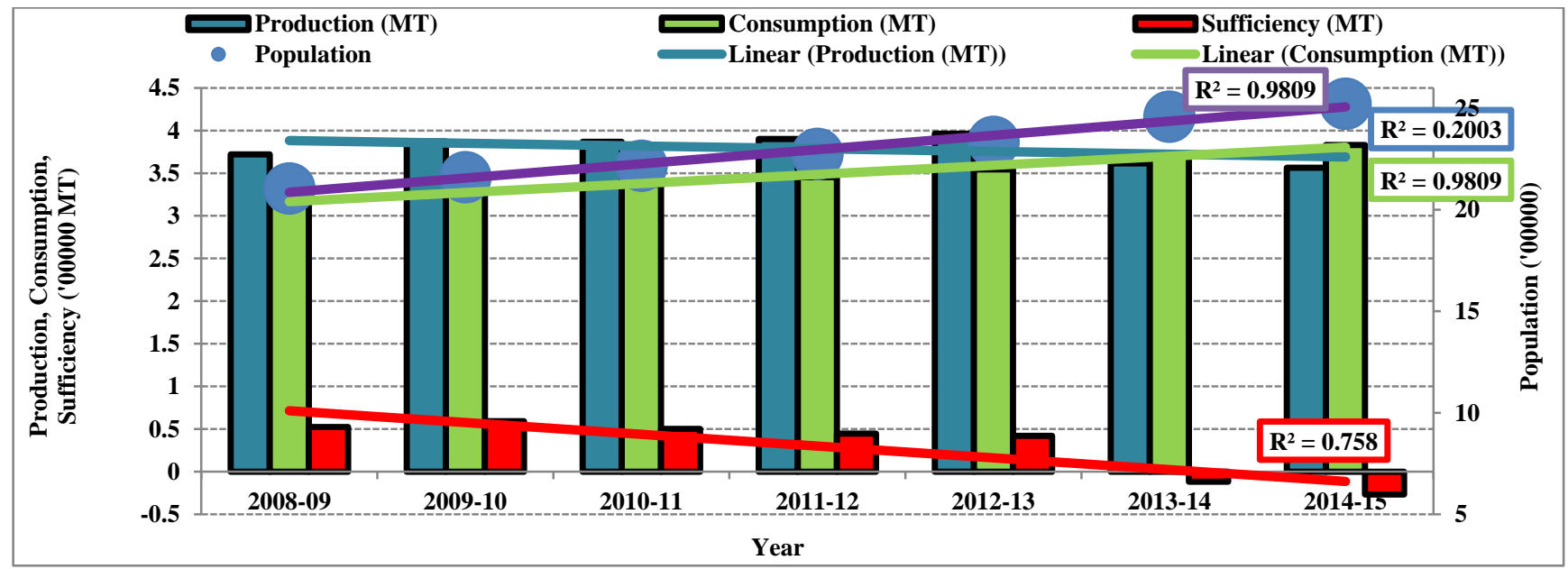

Figure 3. Food sufficiency in Cox's Bazar district. 


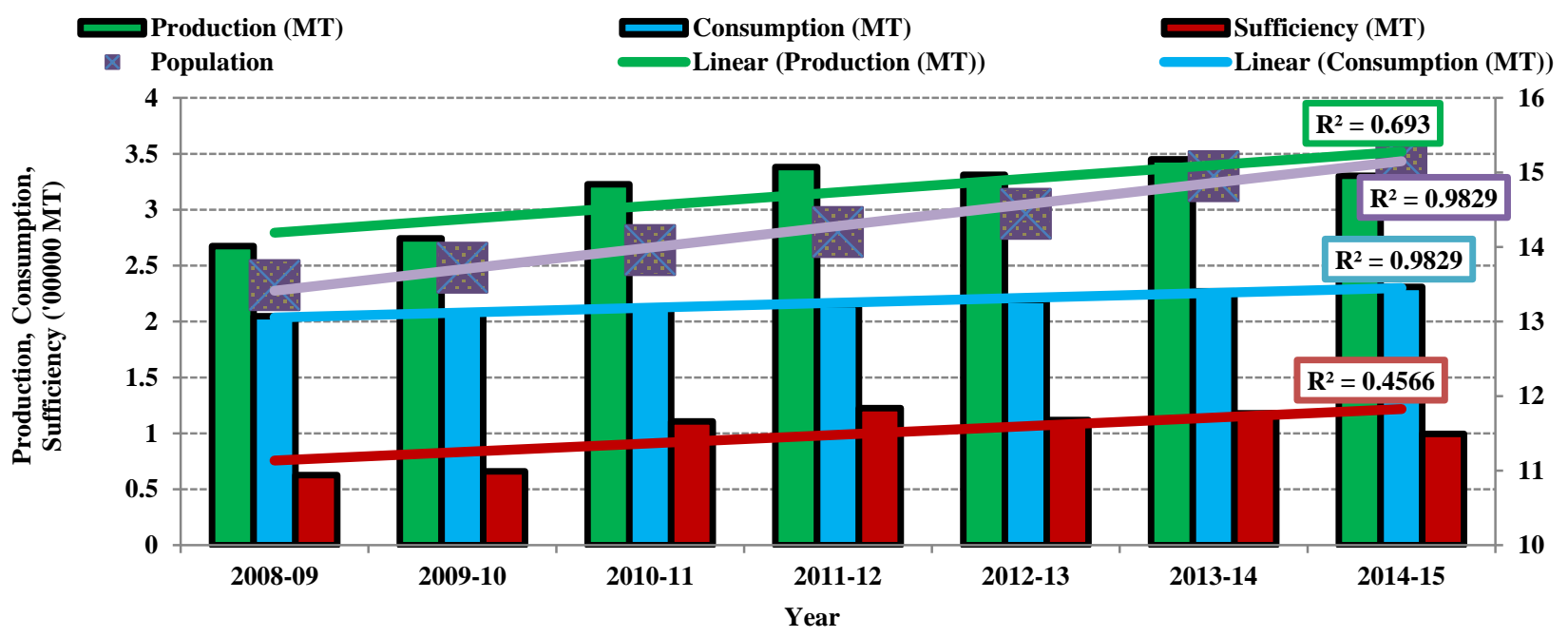

Figure 4. Food sufficiency in Feni district.

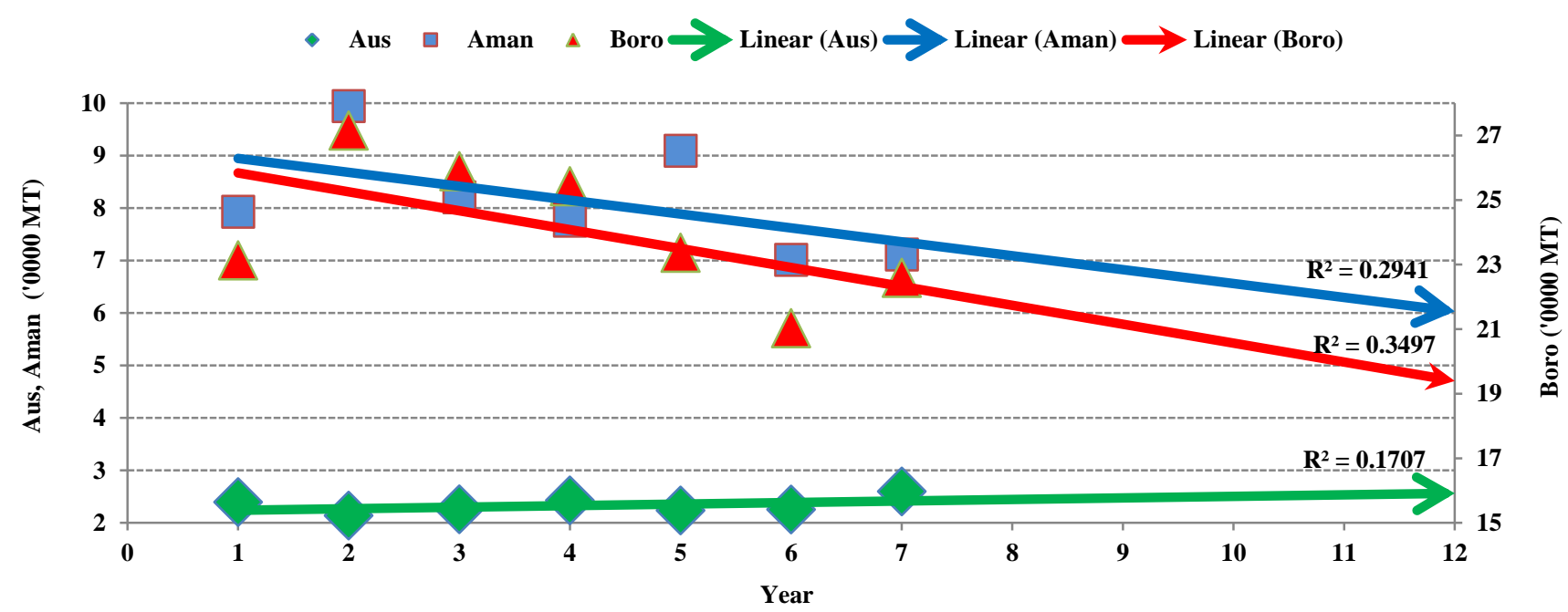

Figure 5. Forecasting of rice grain production in Chandpur district.

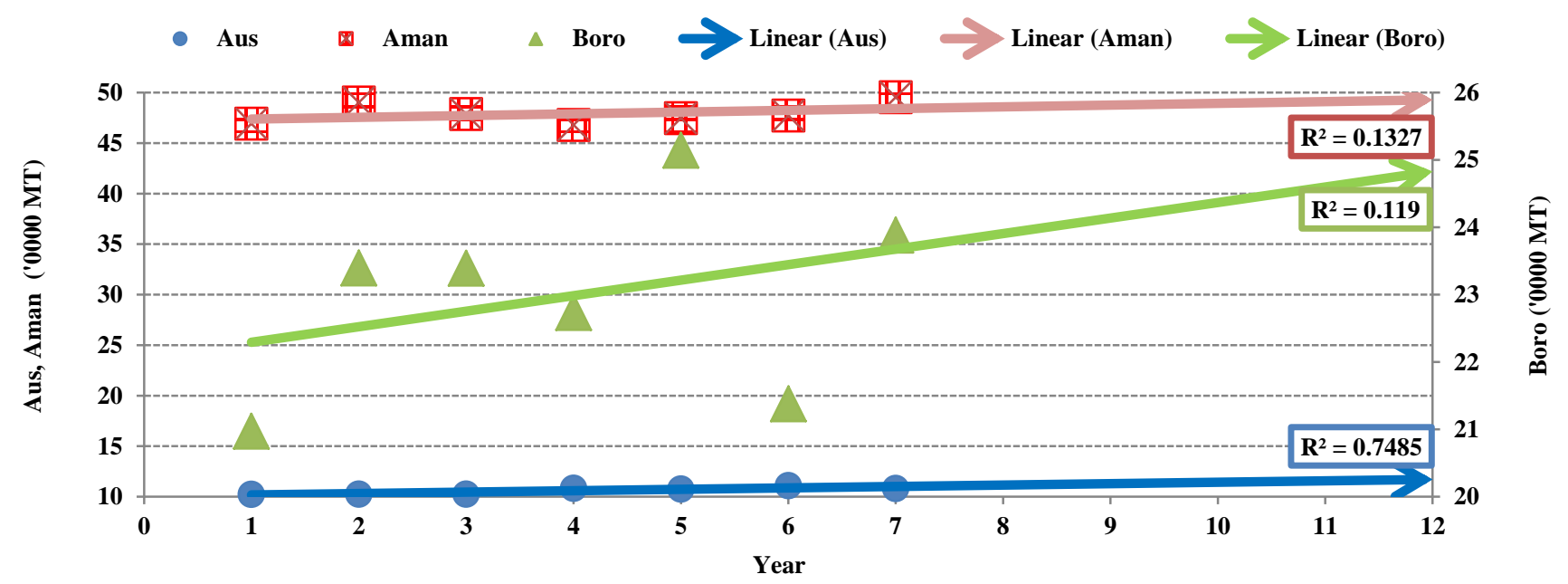

Figure 6. Forecasting of rice grain production in Chittagong district. 


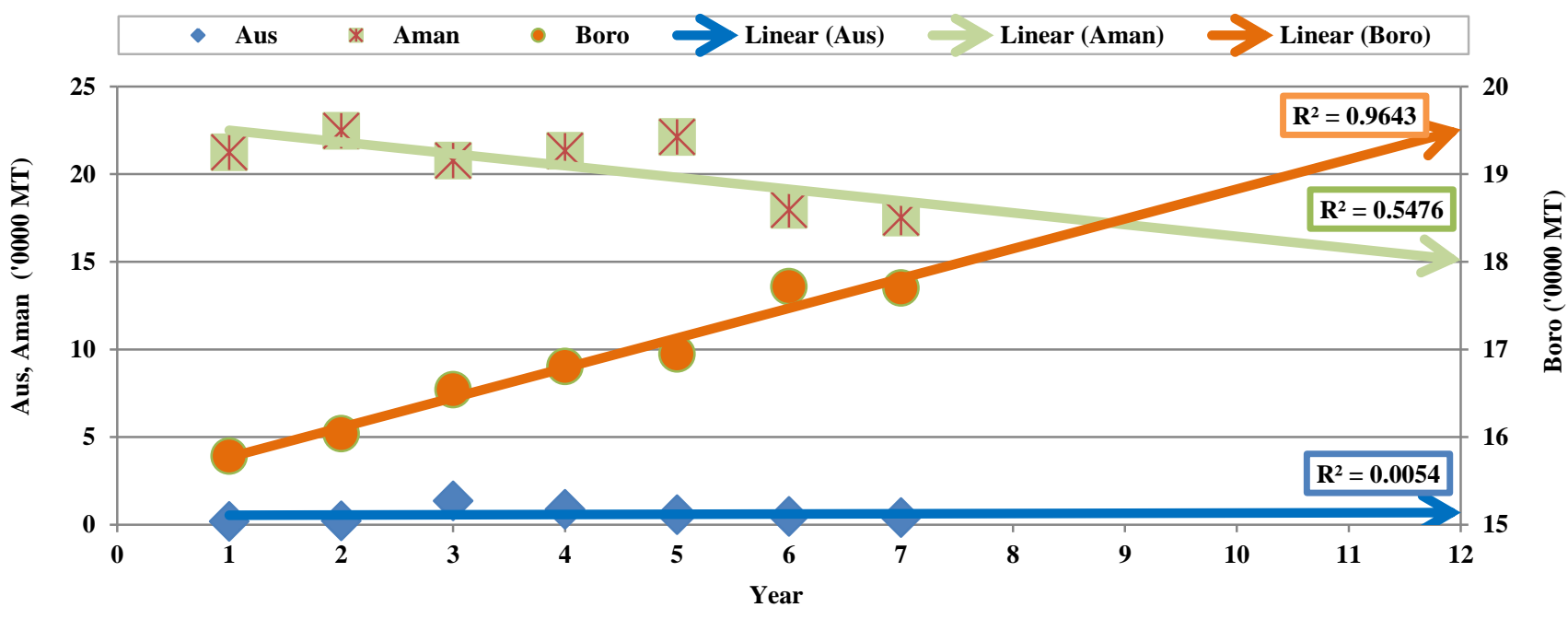

Figure 7. Forecasting of rice grain production in Cox's Bazar district.

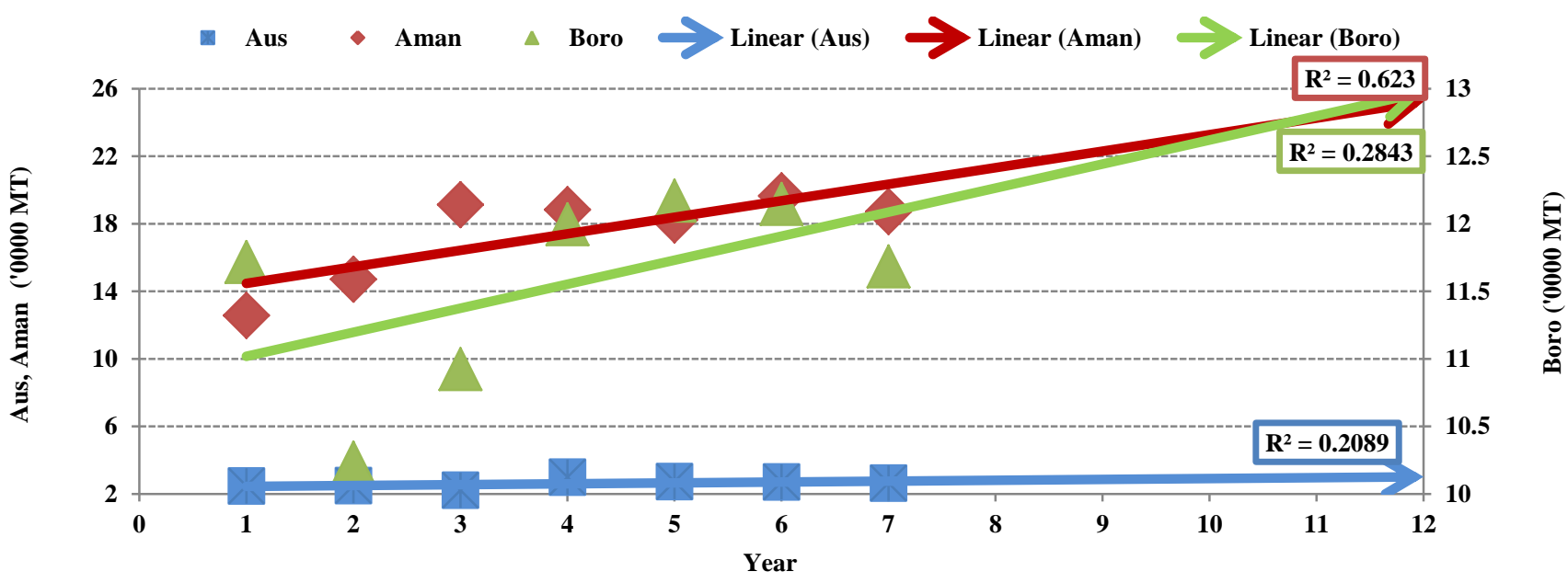

Figure 8. Forecasting of rice grain production in Feni district.

\section{Conclusions}

Bangladesh has made a steady progress in the expansion of food production. The present study finds that, rice production is secure only in Feni district among due to the greater rice production than the consumption. On the other hand, Chandpur and Cox's Bazar district shows production insecurity in the very recent years. But Chittagong district has the production insufficiency from the past to present, because the production is insufficient to meet the demand of the vast population in this area. People of southeastern areas are vulnerable because they live in an extremely dynamic estuarine environment facing many natural threats of climate change and upstream land and water uses. The opportunities and potentials of the coastal zone have not received much attention, and also the disaster mitigation approaches are seen as curative measure rather than protective, which make questions for sustainable coastal belt planning and development. The present study reveals that, the production of Aus rice will be increased in the next 5 years in Chittagong district. Aman rice production will be increased in the next 5 years in the districts namely Feni. Again, Boro rice production will be increased in the next 5 years in the districts namely Cox's bazar, Feni. If the population grows to 233.2 million by the year 2050, then the problem of food insufficiency will be more acute. Currently, maximum area in Bangladesh is under HYV rice cultivation. It is expected that in future the total rice area would be under HYV cultivation. However, even then the rice production is not projected to be adequate to meet the demand. Besides proper management practices (irrigation and fertilizer applications) in southeastern parts of Bangladesh would also help to meet the food demand under changing climatic condition in future. 


\section{Acknowledgements}

The authors are highly obliged and expressing gratification and sincere appreciation the associated all organizations from which we collect data and all respected peoples, who contributed towards the collection of data and samples.

\section{Conflict of interest}

None to declare.

\section{References}

Ali A, 1999. Climate change impacts and adaptation assessment in Bangladesh. Clim. Res., 12: 109-116.

BBS, 2008. The statistical yearbook of Bangladesh, Bangladesh bureau of statistics, planning division, ministry of planning, government of the people's republic of Bangladesh, Dhaka, Bangladesh.

BBS, 2011. The year book of Agriculture Statistics. Bangladesh Bureau of Statistics, Ministry of Planning, Govt. of the People's Republic of Bangladesh, Dhaka, 23-25.

BBS, 2012. The year book of Agriculture Statistics. Bangladesh Bureau of Statistics, Ministry of Planning, Govt. of the People's Republic of Bangladesh, Dhaka.

FANTA, 2006. Food and Nutrition Technical Assistance, Food Security, http://www.fantaproject. Org. html (Last consulted: July 11, 2007).

Gill GJ, J Farrington, E Anderson, T Luttrell, NC Conway, T Saxena and R Slater, 2003. Food Security and the Millennium Development Goal on Hunger in Asia. Working Paper 231. Overseas Development Institute, UK.

Hossain M, F Naher and Q Shahabuddin, 2005. Food security and nutrition in Bangladesh: progress and determinants, J. Agric. Dev. Econ., 2: 103-132.

Huq S, 2003. "Climate Change and Bangladesh: the way forward." Tiempo, Global Warming and the Third world, 47: 13-16.

Jahir AK and R Priya, 2010. A study on partial purification and characterization of extra cellular amylases from Bacillus subtili, R and D division, MRD Life Sciences, Lucknow; SHIATS, Allahabad: Adv. Appli. Sci. Res., 2: 509-519.

Sattar MA and M Moniruzzaman, 2008. "Innovative Rice- based Farming Practices for Increasing Food Security in the Changing Coastal Environment of Bangladesh', in proceedings BKAS 13th National conference and seminar on Climate Changes: Food Security in Bangladesh, Vol. 13, Dhaka, Bangladesh, August.

Petersen L and S Shireen, 2001. Soil and water salinity in the coastal area of Bangladesh. SRDI, Bangladesh.

Rashid MH and MS Islam, 2007. Adaptation to climate change for sustainable development of Bangladesh agriculture. Bangladesh Country Paper, APCAEM, reference evapotranspiration in the Yangtze River basin. Theo. Appl. Climatol., 90: 13-23.

WFP, 2012. World Food Program Food Security in Bangladesh: Papers presented in the national workshop. Ministry of Food and Disaster management, Government of the People's Republic of Bangladesh and World Food Program (WFP), Bangladesh. 